THE FOCUS FOR PHARMACEUTICAL KNOWLEDGE 


\title{
The Focus for Pharmaceutical Knowledge
}

The Proceedings of the Sixth International Meeting of Pharmaceutical Physicians

Brighton, England, June 1987

\author{
Edited by \\ Denis Burley \\ Christobel Haward \\ Brenda Mullinger
}

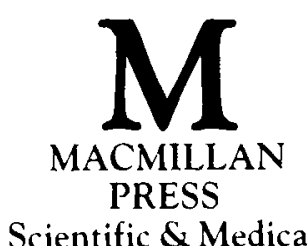


(C) The International Federation of Associations of Pharmaceutical Physicians 1988

Softcover reprint of the hardcover 1st edition $1988 \quad 978-0-333-44356-9$

All rights reserved. No reproduction, copy or transmission of this publication may be made without written permission.

No paragraph of this publication may be reproduced, copied or transmitted save with written permission or in accordance with the provisions of the Copyright Act 1956 (as amended), or under the terms of any licence permitting limited copying issued by the Copyright Licensing Agency, 33-4 Alfred Place, London WC1E 7DP.

Any person who does any unauthorised act in relation to this publication may be liable to criminal prosecution and civil claims for damages.

First published 1988

Published by

THE MACMILLAN PRESS LTD

Houndmills, Basingstoke, Hampshire RG21 2XS

and London

Companies and representatives

throughout the world

Typeset by

Latimer Trend \& Company Ltd,

Plymouth

British Library Cataloguing in Publication Data

International Meeting of Pharmaceutical

Physicians (6th : $1987:$ Brighton, England)

The focus for pharmaceutical knowledge.

1. Pharmaceutics.

I. Title II. Burley, Dennis III. Haward,

Christobel IV. Mullinger, Brenda

$615^{\prime} .19$

ISBN 978-1-349-09573-5 ISBN 978-1-349-09571-1 (eBook)

DOI 10.1007/978-1-349-09571-1 


\section{Contents}

The Contributors

Foreword

ix

Preface

$\mathrm{xiii}$

$\mathrm{XV}$

1. Quality of life 1

G. Teeling Smith

2. Contributions of the pharmaceutical industry to health care D. A. K. Black

3. Failings of the pharmaceutical industry

C. Medawar

4. Improving health care by improving the image of the pharmaceutical industry

H. Schwartz

5. General discussion on pharmaceuticals and health care

6. The future of the pharmaceutical industry

L. C. Hoff

7. Genes, monoclonal antibodies and cancer

K. Sikora

8. Development of biological agents through DNA technology

N. Stebbing

9. Creating a comprehensive and accurate database of efficacy and safety information

R. N. Smith

10. Who needs good clinical practice?

P. A. Nicholson

11. Checks expected by regulatory authorities

$P$. Leber

12. Good clinical practice

B. A. Gennery

13. Clinical pharmacology in industry

D. Jackson

14. Multicentre trials in drug development: good? necessary?

P. E. Lucchelli

15. Phase IV studies: experience in Spain F. G. Alonso

16. Influence of methodology on the results of phase IV studies E. Ambrosioni and E. Strocchi

17. Phase IV: the opportunity and the challenge

L. Lasagna 
18. Concordance of clinical and marketing objectives in phase IV J. J. Schrogie

19. Exploring the clinical properties of marketed drugs E. S. Snell

20. Post-marketing surveillance J.-R. Laporte, X. Carné and D. Capellà

21. US initiatives in post-marketing drug surveillance G. A. Faich

22. Dosage adjustment needed in developing countries

I. Darmansjah and A. Muchtar

23. Developing countries and their rôle in new drug development: a south-east Asian perspective

K. Arnold

24. Clinical trials in parasitic diseases: measurements, controls and ethics

A. Davis

25. Feasibility and credibility of a local R\&D programme in Africa M. Ogrizek

26. Geographical, genetic and environmental factors affecting drug disposition

M. Orme

27. Drug development in the elderly: problems and constraints

P. L. Morselli and P. Guillet

28. Problems in infancy and childhood

G. W. Rylance

29. Orphan drugs - or orphan diseases?

30. Ethics

A. Rosén

31. Obtaining consent in 'special' populations N. Kahn

32. Compensation: responsibilities of the industry to the patient D. M. Burley

250

33. Information for the consumer in the United Kingdom 254 F. Wells

34. Drugs and information for the public in France $Y$. Juillet

35. Information for the consumer in the USA

D. Taylor

36. Re-registration of drugs in the $1990 \mathrm{~s}$

M. G. Bogaert

37. Regulatory requirements in the UK in the 1990s

G. Jones 
38. Drug regulation in the future from the point of view of the industry

$R$. R. Vercoe

39. Consolidating the discipline of pharmaceutical medicine in the United Kingdom

F. J. Gabbay

40. A customized game as an aid for medical representative training

E. G. Brown, L. Brown and D. Stevens

41. Sponsored meetings and publications: a round-table discussion 300

Index 


\section{The Contributors}

\author{
Dr F. Garcia Alonso \\ Technical Director \\ Drug Evaluation Unit \\ Ministry of Health \\ Paeso del Prado 18-20 \\ 28014 Madrid \\ Spain
}

\section{Professor E. Ambrosioni}

Direttore Cattedra di Farmacologia Clinica

Ospedale S. Orsola

Via Massarenti

9-40138 Bologna

Italy

\section{Dr K. Arnold}

Medical Director, Internal Medicine

Roche Far East Research Foundation

PO Box 98595

Tsim Sha Tsui Post Office

Hong Kong

Sir Douglas A. K. Black

Royal College of Physicians

11 St Andrew's Place

Regent's Park

London NW1 4LE

England

\section{Professor M. G. Bogaert}

The J. F. and C. Heymans' Institute of Pharmacology

University of Ghent

De Pintelaan 185

B-9000 Ghent

Belgium

\section{Dr E. G. Brown}

Head of Medical Affairs

Labaz: Sanofi UK Ltd

Floats Road

Wythenshawe

Manchester M23 9NF

England

\author{
Dr D. M. Burley \\ President, IFAPP \\ Ciba-Geigy Pharmaceuticals \\ Wimblehurst Road \\ Horsham \\ West Sussex RH12 4AB \\ England
}

\section{Professor I. Darmansjah \\ Dept of Pharmacology \\ Medical Faculty \\ University of Indonesia \\ 6 Salemba, PO Box 358 \\ Jakarta 10430 \\ Indonesia}

\section{Dr A. Davis}

Director, Parasitic Diseases Programme World Health Organization

CH-1211 Geneva 27

Switzerland

\section{Dr R. Elsdon-Dew}

Director, Medical Services

Glaxo Group Research Ltd

Greenford Road

Greenford

Middlesex UB6 0HE

England

\section{Dr G. Faich}

Director, Office of Epidemiology and Biostatics (HFN-700)

Center for Drugs and Biologics

Department of Health and Human

Services

FDA, Rockville

MD 20857

USA 
Dr F. J. Gabbay

Associate Director

International Clinical Research

Northern Europe

Warner-Lambert (UK) Ltd

Woodside Avenue

Eastleigh

Hampshire SO5 4JQ

England

Dr B. A. Gennery

Group Medical Director (Europe)

Lilly Research Centre Ltd

Erl Wood Manor

Windlesham

Surrey GU20 6PH

England

\section{Dr A. Herxheimer}

Editor, Drugs and Therapeutics Bulletin

Dept of Clinical Pharmacology and Therapeutics

Charing Cross Hospital

Fulham Palace Road

London W6 8RF

England

Dr L. C. Hoff

Chairman of the Board

Pharmaceutical Manufacturers'

Association

110015 th Street, NW

Washington

DC 20005

USA

Dr D. Jackson

Director of Clinical Pharmacology

Beecham Pharmaceuticals

Bioscience Research Centre

Yew Tree Bottom Road

Epsom

Surrey KT18 5XQ

England

Dr G. Jones

Senior Principal Medical Officer

Medicines Division

Department of Health and Social

Security

Market Towers

1 Nine Elms Lane

London SW8 5NQ

England
Dr Yves Juillet

Scientific and Technical Affairs Manager

Syndicat National de l'Industrie

Pharmaceutique

88 rue de la Faisanderie

75782 Paris 16

France

Professor N. Kahn

Dept of Pharmacology

College of Physicians and Surgeons

of Columbia University

630 West 168th Street

New York

USA

Professor M. J. S. Langman

Professor of Medicine

University of Nottingham Medical School

Queen's Medical Centre

Nottingham NG7 2UH

England

Professor J.-R. Laporte

Division of Clinical Pharmacology

Universitat Autònoma de Barcelona

CS de la Vall d' Hebron

08035 Barcelona

Spain

Dr L. Lasagna

Sackler School of Graduate Biomedical Sciences

Tufts University

136 Harrison Avenue

Boston

MA 02111

USA

Dr P. Leber

Director

Division of Neuropharmacological

Drug Products

Food and Drug Administration

HFN/120, Room 10B40

5600 Fisher Lane

Rockville

MD 20852

USA 
Dr S. Lock

Editor, British Medical Journal

BMA House

Tavistock Square

London WC1H WJR

England

Dr P. E. Lucchelli

Medical Director

Mediolanum Farmaceutici

Via C Colombo 49

200090 Trezzano $\mathrm{S} / \mathrm{N}$

Milan

Italy

Dr H. Lyle

Chief Medical Officer

Courtauld Group

7 Astley Close

Leamington Spa

Warwickshire CV32 6PT

England

\section{Mr C. Medawar}

Director

Social Audit Ltd

PO Box 111

London NW1 8XG

England

\section{Dr P. L. Morselli}

Director of Clinical Research

Laboratoire d'Etudes et de Recherches Synthelabo

58 rue de la Glacière

75013 Paris

France

Dr P. Nicholson

Senior Vice President, Medical

Research

G. D. Searle and Company

4901 Searle Parkway

Skokie

IL 60077

USA

\section{Dr M. Ogrizek}

Medical Director, African Region

Warner-Lambert France Ltd

Le Dubon

11 avenue Dubonnet

92407 Courbevoie

France
Professor M. Orme

Professor of Clinical Pharmacology

University of Liverpool

New Medical Building

Ashton Street

PO Box 147

Liverpool L69 3BX

England

Professor A. Rosén

Chairman, Swedish Association of

Pharmaceutical Physicians

Bristol-Myers A B

Hufvudsta Gård

Box 4081

S-17104 Solna

Sweden

\section{Dr G. Rylance}

Consultant Paediatrician

Dept of Paediatric Clin. Pharmacol.

The Children's Hospital

Ladywood Middleway

Birmingham B16 8ET

England

\section{Dr J. J. Schrogie}

President and Chief Executive Officer Philadelphia Association for Clinical

Trials (PACT)

3440 Market Street

Philadelphia

PA 19104

USA

Dr H. Schwartz

PO Box 1169, 50 Argyle Road

Scarsdale

NY 10583

USA

Professor K. Sikora

Royal Postgraduate Medical School

Hammersmith Hospital

Du Cane Road

London W12 0HS

England

Dr R. N. Smith

Director of Medical Services

Glaxo Group Research Ltd

Greenford Road, Greenford

Middlesex UB6 0HE

England 
Dr E. Snell

Consultant

The Association of British

Pharmaceutical Industry

12 Whitehall

London SW1A 2DY

England

Dr N. Stebbing

Research Director

ICI Pharmaceuticals Division

Alderley Park

Macclesfield

Cheshire SK10 4TF

England

Dr D. Taylor

Pharmapolicy Dept

Ciba-Geigy Ltd

CH-4002 Basle

Switzerland
Professor G. Teeling Smith

Director

Office of Health Economics

12 Whitehall

London SW1A 2DY

England

Mr R. R. Vercoe

Head of Regulatory Affairs

Ciba-Geigy Pharmaceuticals

Horsham

West Sussex RH12 4AB

England

Dr F. Wells

Director, Medical Affairs

The Association of the British

Pharmaceutical Industry

12 Whitehall

London SW1A 2DY

England 


\section{Foreword}

It has been my good fortune to be present at most of the meetings sponsored by the International Federation of Associations of Pharmaceutical Physicians. Over the years, I have been impressed repeatedly by the high quality of these gatherings, and the atmosphere in which they are held. The topics covered and the invited speakers have allowed for comprehensive discussion of important problems in a format permitting the expression of different points of view with candor and without an 'agenda', hidden or otherwise.

The physicians in the pharmaceutical industry represent an important and unique force in that industry. They provide a special expertise in both the science and the morality of medical research and the clinical application of the medicines produced by pharmaceutical firms. This is not to say that nonphysicians are either less wise or ethical than physicians; rather, these remarks are intended to emphasize that medical training and personal involvement in the care of the sick can provide a perspective not obtainable in any other way.

During its relatively short lifetime, the International Federation of Associations of Pharmaceutical Physicians has grown in a highly satisfying fashion. It now has 20 affiliated organizations and the Federation's newsletter reaches nearly 4000 pharmaceutical physicians around the world. The outstanding 'missing link' is the United States. For reasons which I do not comprehend, there is no association of pharmaceutical physicians in my own country. I hope that by the time that the next international meeting is held, the United States will join its sister nations in the praiseworthy efforts of the Federation.

The meeting whose proceedings are described in this book was a splendid one in every respect, with spirited treatment of important topics not often covered in scientific meetings. Its high quality indicates that the International Federation continues to perform a key function in our society's attempt to deal with one of its most important tasks - to discover, and to provide the public with, new and better medicines.

Louis Lasagna

Tufts University

Boston, USA 


\section{Preface}

This publication is in essence a report on the sixth of a series of meetings held every three years by the International Federation of Associations of Pharmaceutical Physicians. The first meeting was held in London in 1972, and it was there that discussions took place which led to the formation of IFAPP. Subsequently the growing importance of pharmaceutical medicine was recognized through meetings in Florence, Brussels, Paris, Munich and Brighton.

Over the years there has been a change in emphasis in the subjects which generate particular interest for pharmaceutical physicians and the industry for which they work. The content of the Brighton meeting reflected this. At these meetings there will always be great interest shown and lively discussion of topics, such as animal toxicity data and their relevance, design and conduct of clinical trials, drug interactions and problems of drug regulation in different parts of the world. The need for a more integrated and better system of post-marketing surveillance of medicines has been sharpened by widespread public and media concern over adverse reactions encountered with certain groups of medicines. This has led to company or licence withdrawals.

Today, concern over health care is demonstrated world-wide, and as a result the pharmaceutical industry must be responsive to its international rôle as one of the chief providers of the means to combat illness. It is significant that the first plenary session was concerned with pharmaceuticals and health care, with a subsequent keynote lecture on the future of the pharmaceutical industry. In other sessions, clinical trials in developing countries, orphan drugs and information about medicines required by the consumer were considered. Controversial subjects were not avoided and there was animated participation in discussions on sponsored meetings and publications, the use and abuse of phase IV clinical trials, the use of volunteer subjects, consent and compensation.

Every three-year period between each international meeting brings with it advances in technology and new ideas for handling data and assessing response in clinical trials. The sessions on biotechnology, data measurement, and the measurement of quality of life are reflections of this progress. The establishment of pharmaceutical medicine as a significant medical discipline has implications for pharmaceutical physicians and non-medical scientists involved in all aspects of drug development, regulation and monitoring. It was pertinent that training and careers in the pharmaceutical industry should feature as a topic for discussion, and it is likely that at future meetings there will be increasing collaboration with non-medical groups involved in all 
aspects of drug development, under the broad heading of pharmaceutical medicine, with perhaps less concentration on the rôle of the pharmaceutical physician.

We look forward to the next international meeting in Spain in 1990 and wish our AMIFE colleagues every success. There is much hard work to be done, but accomplishment of an aim is in itself rewarding. Success cannot be achieved without unstinting help from colleagues and friends. Therefore I would like to take this opportunity to thank Robert Smith, Brian Marsh, Geoffrey Venning on the scientific programme committee, and Robin Elsdon-Dew, Ian Lennox-Smith, Julian Ruiz-Ferrán, Richard Rondel, David Lott, Christopher Mugglestone, together with Enid Oldrini, Sharron Ashburner, Sally Priest and Christobel Haward, on whose shoulders the greatest organizational problems fell.

Finally I pay tribute to the late Bill Burland, who organized the first meeting and at the time of his death had started to guide us through this, the sixth meeting. It is to him that this volume is dedicated.

Horsham, 1988

D.B.

C.H.

B.M. 